University of Nebraska - Lincoln

DigitalCommons@University of Nebraska - Lincoln

Agronomy \& Horticulture -- Faculty Publications

Agronomy and Horticulture Department

1985

\title{
Dhurrin and $p$-Hydroxybenzaldehyde in Seedlings of Various Sorghum Species
}

Francis A. Haskins

University of Nebraska-Lincoln, fhaskins@neb.rr.com

H. J. Gorz

University of Nebraska-Lincoln

Follow this and additional works at: https://digitalcommons.unl.edu/agronomyfacpub

Part of the Plant Sciences Commons

Haskins, Francis A. and Gorz, H. J., "Dhurrin and p-Hydroxybenzaldehyde in Seedlings of Various Sorghum Species" (1985). Agronomy \& Horticulture -- Faculty Publications. 171.

https://digitalcommons.unl.edu/agronomyfacpub/171

This Article is brought to you for free and open access by the Agronomy and Horticulture Department at DigitalCommons@University of Nebraska - Lincoln. It has been accepted for inclusion in Agronomy \& Horticulture -Faculty Publications by an authorized administrator of DigitalCommons@University of Nebraska - Lincoln. 


\title{
DHURRIN AND $p$-HYDROXYBENZALDEHYDE IN SEEDLINGS OF VARIOUS SORGHUM SPECIES*
}

\author{
F. A. HASKINS and H. J. GorZ \\ Department of Agronomy, University of Nebraska and USDA-ARS, Lincoln, NE 68583, U.S.A.
}

(Received 10 August 1984)

Key Word Index-Sorghum species; Gramineae; dhurrin; p-hydroxybenzaldehyde; cyanogenesis.

\begin{abstract}
Week-old shoots of 50 Sorghum entries representing 22 species, plus four Sorghum entries of undesignated species, were dried at $75^{\circ}$ and the dried tissue extracted with water at room temperature. The resulting extracts were diluted in $0.1 \mathrm{M}$ sodium hydroxide and spectra were scanned immediately to provide a measure of free $p$ hydroxybenzaldehyde. Scans were repeated after the basic solutions had stood for $3 \mathrm{hr}$ at room temperature to permit hydrolysis of dhurrin ( $S$-p-hydroxymandelonitrile $\beta$-D-glucopyranoside). Without exception, the quantity of free $p$ hydroxybenzaldehyde was very small in relation to the quantity released by dhurrin hydrolysis.
\end{abstract}

Woodhead et al. [1] observed that free p-hydroxybenzaldehyde (1) makes up as much as $30 \%$ of the wax of Sorghum bicolor seedlings. This observation raised doubts as to the validity of a dhurrin $(S$-p-hydroxymandelonitrile $\beta$-D-glucopyranoside) assay that we have used extensively. In this assay Sorghum seedling tissue is autoclaved in water to extract and simultaneously hydrolyse the dhurrin, and the liberated 1 is determined spectrophotometrically to provide a measure of dhurrin content [2]. Following the report of Woodhead et al. [1], we did a series of experiments with several Sorghum cvs. from which we concluded that free 1 was not present in appreciable quantity on the surface or within young shoots that had been heated to inactivate hydrolytic enzymes [3]. Subsequently, Woodhead et al. [4] have stated that, although the occurrence of free 1 in Sorghum seedlings is "clearly a restricted phenomenon with many cultivars having little or no free 1", seedlings of cv. 65D from Botswana and one other cultivar, not identified, contained 1 in the surface wax.

The possibility that free 1 might occur in seedlings of some but not all Sorghums led us to the experiments reported here in which we have examined seedlings of a diverse group of 54 Sorghum accessions for the presence of this compound.

\section{RESULTS AND DISCUSSION}

Extracts from shoots of 1-week-old seedlings of each sample (dried at $75^{\circ}$ for $2.5 \mathrm{hr}$ ) were made in water and diluted with $0.1 \mathrm{M}$ sodium hydroxide. Each basified extract was scanned from 400 to $240 \mathrm{~nm}$ immediately after dilution, and scans were repeated after the solutions had

"Contribution from the Nebraska Agricultural Experiment Station and the Agricultural Research Service, U.S. Department of Agriculture. Published as paper No. 7540, Journal Series, Nebraska Agricultural Experiment Station. The work reported was conducted under project 12-114, Nebraska Agricultural Experiment Station. stood at room temperature for $\mathrm{ca} 3 \mathrm{hr}$ to allow hydrolysis of dhurrin.

All initial spectral scans were similar in that each lacked a well-defined peak at $330 \mathrm{~nm}$ (the UV $\lambda_{\max }$ of 1) but had a definite peak at $255 \mathrm{~nm}$ (the UV $\lambda_{\max }$ of dhurrin in alkaline solution). After $3 \mathrm{hr}$, each scan had a strong $330 \mathrm{~nm}$ peak and had lost the $255 \mathrm{~nm}$ peak. Based on the $A_{330}$ values obtained, the total concentration of 1 for all 54 entries (mean \pm s.e.) was $19.6 \pm 1.4 \mu \mathrm{mols} / \mathrm{g}$ fr. tissue.

For most entries, the increase in $A_{330}$ accompanying the basic hydrolysis of dhurrin was greater than 10-fold; the mean $A_{330}$ (initial) $/ A_{330}$ ( $3 \mathrm{hr}$ ) ratio being 0.092 \pm 0.005 . All initial scans were relatively flat in the region between 400 and $320 \mathrm{~nm}$. This flatness is illustrated by the $A_{380} / A_{330}$ ratio which was $1.03 \pm 0.03$ for initial scans, in contrast to $0.099 \pm 0.005$ for $3 \mathrm{hr}$ scans.

It was clear from the spectral scans that interference with the $A_{330}$ maximum of 1 was relatively much greater in the initial scans than in those made at $3 \mathrm{hr}$ and that use of the initial $A_{330}$ readings for calculation of the concentration of free 1 would lead to highly inflated values. An indication of the extent of this inflation is provided by other work with 10 cultivars and lines of S. bicolor, one of which was $65 \mathrm{D}$. Dried, ground 1-week-old shoots were extracted with either chloroform or, in some instances, with water followed by ether extraction of the aqueous extracts. Scans of the chloroform and ether extracts indicated that less than $1 \%$ of the total content of 1 was present in the free form ([3] and unpublished results). Thus, the true ratio of free to total 1 is probably closer to 0.01 than to the 0.092 value shown above. We conclude that little, if any, free 1 existed within or on shoots of any of the entries included in this study.

With respect to content of free 1 we found cv. $65 \mathrm{D}$ to be similar to all other Sorghums included in the study. We are unable to explain the lack of agreement between our results and those of Woodhead et al. [4] with this cultivar.

\section{EXPERIMENTAL}

Plant materials. Seeds of 53 entries were obtained from the U.S. Department of Agriculture Regional Plant Introduction Station, 
Experiment, Georgia. Included were one accession of Sorghum aethiopicum, three of almum, three of arundinaceum, three of bicolor, four of caudatum, one of controversum, one of halepense, two of hewisonit, one of japonicum, one of miliaceum, three of nigricans, one of niloticum, three of notabile, one of plumosa, one of propinquum, one of pugionifolium, four of saccharatum, two of subglabrescens, seven of sudanense, one of versicolor, three of verticillifiorum, two of virgatum and four accessions designated only as Sorghum sp. In addition, cv. 65D (S. bicolor) was obtained from L. M. Mazhani, Department of Agricultural Research, Gaborone, Republic of Botswana. In total, 50 entries representing 22 species plus four entries without species designation were included in the study. Seedlings were grown as previously described [2]. Samples usually consisted of a bulk of five shoots from 1-week-old seedlings.

Sample treatment and spectral scanning. Samples were weighed, dried at $75^{\circ}$ for $2.5 \mathrm{hr}$, pulverized and extracted with $20 \mathrm{ml} \mathrm{H}_{2} \mathrm{O}$ at room temp. for $2 \mathrm{hr}$. The tissue residue was removed by filtration and filtrates were diluted 10 -fold with $0.1 \mathrm{M} \mathrm{NaOH}$ for spectral scanning.

Acknowledgement-The excellent technical assistance of Carol Caha is gratefully acknowledged.

\section{REFERENCES}

1. Woodhead, S., Galeffi, C. and Bettolo, G. B. M. (1982) Phytochemistry 21, 455.

2. Gorz, H. J., Haag, W. L., Specht, J. E. and Haskins, F. A. (1977) Crop. Sci. 17, 578.

3. Haskins, F. A. and Gorz, H. J. (1983) Phytochemistry 22, 611.

4. Woodhead, S., Galeffi, C. and Bettolo, G. B. M. (1984) Phytochemistry 23, 197. 